\title{
The Analysis of “Anak Pintar Seri English? No Problem!” For English Language Learning
}

\author{
Rika Hendryani, Petra Christian University, Surabaya, Indonesia \\ rikahendryani@gmail.com
}

\begin{abstract}
The present study is aimed to find out the extent to which Anak Pintar seri English? No Problem! meet the 10 principles for designing video games for foreign learning proposed by Purushotma, Thorne, and Wheatley (2009). This study is a qualitative research that took the writers approximately 5 hours to play. The findings of this study show that Anak Pintar seri English? No Problem! matches 5 principles, for example, the principles of "content organized around tasks" and "metalinguistic descriptions and terminology presented as a supporting material". The result of this study hopefully would be beneficial to the studies of video games for foreign language learning and for those that wish to evaluate or use video games as a learning tool.
\end{abstract}

Keywords: video games, language learning, EFL

Many video games for language learning have been developed in Indonesia; and one of them is Anak Pintar seri English? No Problem!. This video game was developed by PT. Akal Interaktif (Akal EduMovie, 2012). It has three levels of difficulty: easy, normal, and hard. In this video game, the players play as a detective solving a crime given by a client (2012). While solving the crime, the players are able to learn various points of grammar such as, modals, gerunds, infinitives, declarative and questions sentences, comparison, preposition, present simple tense, present continuous tense, past simple tense, etc. (2012).

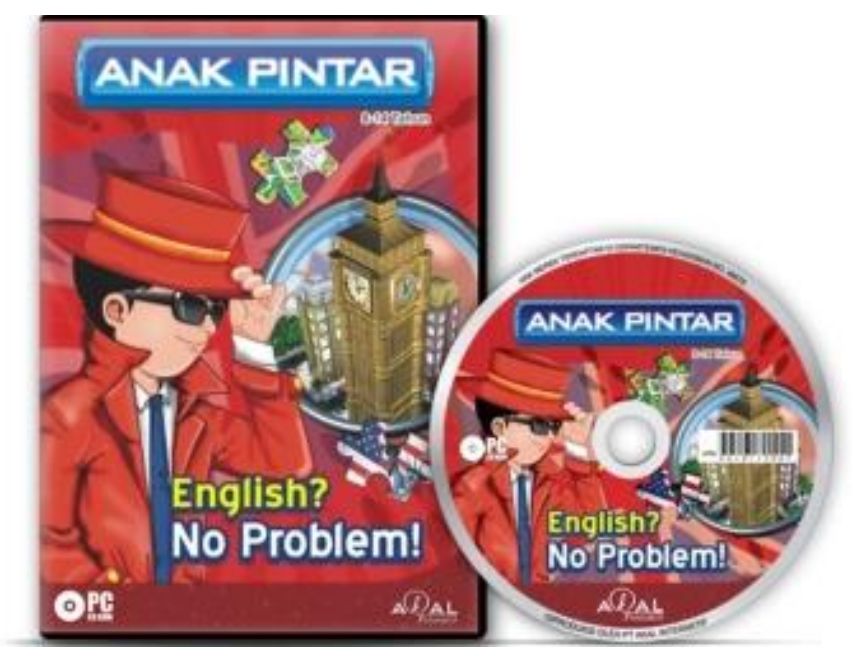

Figure 1. Front cover of Anak Pintar seri English? No Problem! CD (Akal Interaktif, 2017) 


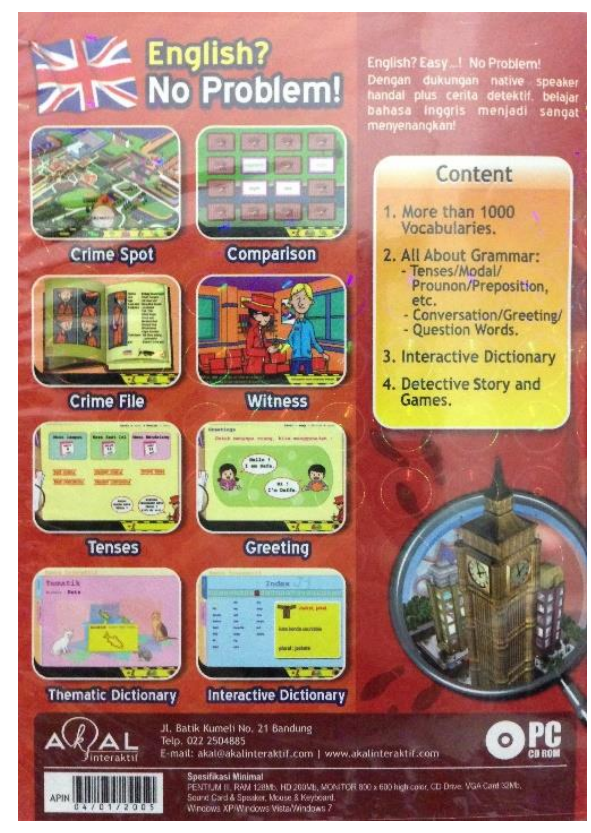

Figure 2. Back cover of Anak Pintar seri English? No Problem!

(Akal Interaktif, 2017)

To enable users or players of video games achieve the ultimate benefits of learning additional language through video games, Purushotma, Thorne, and Wheatley's (2009) have proposed 10 key design principles that should be used as a guideline for game developers in developing video games for language learning. The 10 key design principles are:

1. At least as much thought needs to go into the design of failure states as for success states.

2. Instruction needs to ensure that learners focus predominantly on meaning; secondarily, however, instruction should still include focus on form.

3. All elements of the game, particularly communication and input mechanisms, should have a playful spirit to them.

4. Metalinguistic descriptions and terminology should be presented through optional supporting material, not as part of the core gameplay.

5. Learning content should be organized around tasks, not presented taxonomically.

6. New concepts should be introduced gradually and interspersed with other content before requiring difficult responses from players.

7. Assessment should intelligently track free production tasks throughout the game, not simply measure controlled production during test events.

8. Consider the full range of gaming platforms available.

9. Games should allow students to spend extra time in activities they enjoy and to minimize time in ones they don't. Ultimately, instructional activities should be designed to teach students how they can autonomously continue playing similar games or performing similar activities taken directly from the target culture.

10. Where possible, multiplayer games should provide players with meaningful and distinct roles.

(Purushotma, Thorne, and Wheatley, 2009, pp. 8-27)

This study was done to find out to what extent does Anak Pintar seri English? No Problem! meets the principles for designing video games for foreign learning proposed by Purushotma, Thorne, and Wheatley (2009).

\section{METHODS}


This study used qualitative approach, particularly content analysis. The data collection was done through the writers' personal experience in playing Anak Pintar seri English? No Problem! for approximately 5 hours.

\section{FINDINGS AND DISCUSSION}

Overall, the writers found that in Anak Pintar seri English? No Problem! met half of the design principles proposed by Purushotma, Thorne, and Wheatley (2009). The details are provided below.

\section{Principle \#1}

In general, there are two responses for success states in Anak Pintar seri English? No Problem!. First, the players can hear a 'ding' sound as an approval for the correct answer. Second, the game gives the players visual response, i.e., approval remark that the answer is correct (e.g. "YES! YOU'RE RIGHT"). In sentence structure game, the players also receive the answers of the questions in the games. Also, the players will receive a clue that is crucial to solve the crime as a reward in succeeding.

The responses in the failure states are slightly similar to the success responses. The players also receive both sound and visual response. One difference is that the system will automatically reduce the number of the players' lives when they make mistakes. Furthermore, in vocabulary focused game, correct answers are not revealed when the players make mistakes. Only in sentence structure games do they receive answer revelation as a response.

The findings concluded that Anak Pintar seri English? No Problem! respond successes and failures mainly using sound and visual remarks. Only in sentence structure games do players receive direct answer revelation as feedback. According to Purushotma, Thorne, and Wheatley (2009), feedback that is needed more in video games for foreign language learning video games is creative feedback. Creative feedback does not give direct solution, but memorable cues and clues that guides the players to understand the choices they make (2009).

\section{Principle \#2}

Anak Pintar seri English? No Problem!'s games are form-focused rather than meaning-focused. The games mostly center on memorizing basic words meaning, words spellings, and words order. For example, the library's game in the normal level focused on word order because the players are required to arrange jumbled words to form sentences with modals (i.e., can, could, may, might, must, will, would). Another example is the hangman game in the harbor area that asks the players to translate and spell an Indonesian word to English by clicking on the alphabets given. This makes the hangman game a formfocused game because it focuses on word spellings.

Although being able to order and spell words correctly is important, there is a concern that such activities do not help in making the players understand the contexts that are needed to determine how the word is used (Purushotma, Thorne, \& Wheatley, 2009).

\section{Principle \#3}

The mechanism to input answers in Anak Pintar seri English? No Problem! can be categorized as rapid because of two reasons. First, the ways to input answers to most of the games in Anak Pintar seri English? No Problem! do not require the players to type out answers; only one game in the hard level does. The easy level requires the players to click and/or drag the mouse. In the normal level, the players must use the mouse and arrow keys on the keyboard. The hard level requires the players to use mouse, arrow keys and to type out sentences. Although typing out sentences could be considered slow, but this mechanism is only needed in one game in the hard level, i.e., flower shop's game. Also, the flower shop's game does not have a timer. The players, therefore, can take their time in making the sentences.

Second, the games provide the players with items to answers the questions or complete the task instead of asking the players to produce their own output. For example, in sentence structure games the 
players are provided with several words. These words if arranged correctly can create a sentence. In this way, the players do no need to construct or input their own words.

Anak Pintar seri English? No Problem!, therefore, provides fast ways to input answers and also items to help the players answer questions. This mechanism allows rapid constructions and at the same time it gives the players to think through the steps in constructing, which is they key of the $3^{\text {rd }}$ principle (2009).

\section{Principle \#4}

The metalinguistic descriptions and the terminology in Anak Pintar seri English? No Problem! function as a supporting material. There is a grammar bank in each level that covers brief lectures of different grammar topics. The easy level covers 5 points of grammar, the normal level covers 8 points of grammar, while the hard level covers 11 points of grammar. The grammar bank can be accessed easily through the main area of the game or when playing by clicking on the 'GRAMMAR' icon on the bottom right of their screen.

The current finding is in agreement with Purushotma, Thorne, and Wheatley's statement that metalinguistic concepts should not need to be named as long as the players can use these them correctly (2009). By doing this, the players will be able to focus and enjoy accomplishing tasks with no pedagogical intervention.

\section{Principle \#5}

In Anak Pintar seri English? No Problem!, the learning content is presented through taxonomical grouping and simultaneously organized around the task of being a detective. An example of this is the game in the crime spot area in the easy level. In this game, the players have to match the word given by the system to its corresponding picture. This game focuses on only teaching the players vocabularies of common household items. When the players succeed in the game, they will receive a clue that is crucial in solving the crime.

As can be seen from the example, the game only focuses on teaching vocabularies, but it is incorporated with the task of finding clues to solve the crime. This results in Anak Pintar seri English? No Problem!'s learning content being organized partially around task and partially taxonomically. This result may be related to the game being more form-focused that meaning-focused.

Although the finding is not completely in line with the principle, teaching taxonomically has its advantage. One advantage of teaching taxonomically through form-focused activity is that it often pays more attention to linguistic accuracy than meaning-focused tasks that ignore linguistic errors (Nishimura, 2000). This is useful for the players who are still in their early phase of learning.

\section{Principle \#6}

In Anak Pintar seri English? No Problem!, there are 3 levels of difficulty: easy, normal, and hard. Each level has different number of grammar topics. The easy level has 5 major points of grammar, the normal has 8 , while the hard has 11 points of discussion.

The level of difficulty influences the task of the games inside each level. One example is the flower shop's game in each level that requires the players to do different task. The easy level requires the players to arrange some jumbled words to make present simple, present continuous, or past simple yes or no questions. The normal level's task is to complete present simple, present continuous, or past simple questions with the appropriate question words or question tags. The hard level asks the players to type down an indirect sentence based on the direct sentence the system provides.

The findings showed two things. One, new concepts are introduced gradually as the level of difficulty increases. Also, the task requires more difficult response from the players as the grammar topics increases in each level. This allows the players to "progress from each stage to the next as their internal system is ready to do so" (Purushotma, Thorne, \& Wheatley p.20).

\section{Principle \#7}


The players are assessed on their ability to successfully catch the criminal by finishing all activities and retrieving all clues. However, there is no mechanism in Anak Pintar seri English? No Problem! that tracks or records the players progress throughout the game. Therefore, it is hard to know if the players do comprehend the materials or not.

Moreover, there is no mechanism that is able to detect if the players realize the mistakes they made or not when playing. Such mechanism is needed in the game because being able to realize one's own mistake can be seen as considerably further in the process of learning (Schimdt, 1990, as cited in Purushotma, Thorne, and Wheatley, 2009).

\section{Principle \#8}

Anak Pintar seri English? No Problem! CD program can only run on Windows (XP/Vista/7) operating system. Since most computer today mostly run on Windows 10 operating system, it might be better if the game designers start to update the operating system of Anak Pintar seri English? No Problem! to Windows 10.

\section{Principle \#9}

1. The players are given the freedom to choose the activities or games they want to do in Anak Pintar seri English? No Problem!. There is no particular sequence that the players have to follow, as long as they complete all activities in the end. Moreover, these activities can be played repeatedly. This allows the players to spend more time on activities they like and enjoy.

Anak Pintar seri English? No Problem! provides a more comfortable learning environment for the players by giving the players a chance to think and make their own choices. The players can play and learn according to their own pace. They do not have to move on to another level if they are not ready to do so. This can lower the anxiety level of the players and at the same time build their confidence in playing. According to the Affective Filter Hypothesis, low level of anxiety, high motivation, and high self-confidence will result in language learners receiving more input; and more input will help the development of language learning (Krashen, 1982)

In addition, the design of Anak Pintar seri English? No Problem! that allows the players to take charge of their own actions can open up the possibility of the players playing similar games or activities outside the game (Purushotma, Thorne, and Wheatley, 2009). Some example of similar activities that the players can perform outside the game are greeting people in English or play a role-playing game as a detective.

\section{Principle \#10}

Anak Pintar seri English? No Problem! is a single-player game. The players cannot play with other players at the same time. The game does allow the players to register up to 3 different player accounts; but these accounts cannot be used to play the same game at the same time.

Despite the lack of other players in the game, the game still provides meaningful role to the players. The role that the players play as is a detective solving a case for a specific client. The role is supposedly designed to motivate and give a sense of personal responsibility to the players to solve the case.

\section{CONCLUSION AND SUGGESTION}

This paper has investigated the extent of Anak Pintar seri English? No Problem! meeting the principles for designing video games for foreign learning proposed by Purushotma, Thorne, and Wheatley (2009). The findings revealed that Anak Pintar seri English? No Problem! to some extent met 5 design principles proposed by Purushotma, Thorne, and Wheatley (2009): the $3^{\text {rd }}, 4^{\text {th }}, 5^{\text {th }}, 6^{\text {th }}$, and $9^{\text {th }}$ principles. 
It is hoped that the findings of this study would be beneficial to the studies of video games evaluation. The writers also hope that further studies analyzing the underlying principles of other foreign language learning video game can be carried out in the future.

\section{REFERENCES}

Akal EduMovie. (2012, February 7). Belajar Bahasa Inggris bersama Anak Pintar - English? No Problem! [Video File]. Retrieved February 7, 2017 from https://www.youtube.com/watch?v=myS3aqBFNa4

Akal Interaktif. (2017). Anak Pintar seri English? No Problem! CD [Online image]. Retrieved June 26, 2017 from http://beranda-anak.com/anak-pintar/57-english-no-problem-.html

Nishimura, K. (2000). Effective ways of communicative instruction in the Japanese EFL classroom : Balancing fluency and accuracy. Retrieved February 21, 2017, from http://files.eric.ed.gov/fulltext/ED442297.pdf

Purushotma, R., Thorne, S.L., \& Wheatley, J. (2008). 10 key principles for designing video games for foreign language learning. Retrieved 10 January, 2017 from http://pdxscholar.library.pdx.edu/cgi/viewcontent.cgi?article=1008\&context=wll_fac

\section{ACKNOWLEDGMENT}

This paper was based on some parts of the primary author's BA thesis submitted to Petra Christian University, Surabaya (Indonesia). This paper was also a part of the primary author's presentation at the 5th Undergraduate Conference on ELT, Linguistics, and Literature conference. 